\title{
Temporal and Spatial Scale Community Level Water Use in Saskatchewan
}

\section{Ana-Maria Bogdan ${ }^{1}$ and Suren Kulshreshtha ${ }^{2^{\star}}$}

${ }^{1}$ School of Environment and Sustainability, University of Saskatchewan, Saskatoon, SK, S7N 5C8, Canada

${ }^{2}$ Department of Bioresource Policy, Business and Economics, College of Agriculture and Bioresources, University of Saskatchewan, Saskatoon, SK, S7N 5A8, Canada

\begin{abstract}
Water is being recognized as an increasingly valuable natural resource, requiring evermore complex and challenging decision-making. Forecasts under probable scenarios have the potential to inform development of comprehensive water management strategies. This study was conducted to determine the current and future community level (domestic plus municipal) water use across Saskatchewan, fewer than three different scenarios: business as usual, climate change, and water conservation. These water uses were estimated at four different temporal scales-2010, 2020, 2040, 2060, as well as at three different spatial scales-community, river basin and province. The methodology for the estimation of these water uses was designed by estimating population for various communities and their respective water use on a per capita basis, with adjusted water use coefficients for the climate change and conservation scenarios. Trend analysis was undertaken using time series data for the period 1995 to 2009. Results indicate that in 2010 a total of 166,919 dam $^{3}$ (equivalent to 44,158 U.S. gallons) of water was required to meet these uses which would increase to 206,530 dam $^{3}$ (or 54,638 U.S. gallons) by 2060 -an increase of $23.7 \%$. Furthermore, climate change could bring forth a further increase in this use of nearly $6 \%$ over the baseline scenario by 2060 , while with adoption of water conservation practices, the 2060 level of community water use could be reduced by $12.5 \%$.
\end{abstract}

Keywords: Water; Community; Saskatchewan; Domestic water use; Water demand forecast; Scenario planning; Community; Canada

\section{Introduction}

Water use in communities is a sum of various types of uses, although residential water use is the prominent one. In addition, in many large communities, industrial and commercial water use as well as public water use (street cleaning, firefighting, another other) is also present. All these uses are combined into community water use in this study.

\section{Global Challenges of Water Management}

Management of water resources in a dynamic socioeconomic context-population growth, water use patterns changes, competing water users, and uncertain future environmental conditions including hydrological cycle changes brought forward by climate change, raises serious challenges for water managers [1]. Across the world increased pressure is being put on water resources, which not only affects our socioeconomic well-being, but also undermines the well-functioning of ecosystems on which we depend [2,3]. These socio-ecological systems are complex dynamic systems of processes for which we have limited understanding, making it difficult to predict their future developments. While in the past, water management and governance have focused on water-supply management-building dams and reservoirs, to assure water sufficiency, in the last few decades, water-demand managementencouraging users to conserve water through education, price signals, subsidies, has been recognized as an important policy approach. However, to develop sustainable water management strategies and policies, the starting point is knowledge of current and future water demands. In recent reports by United Nations [4] and NRTEE [5], as well as other scholars in this area [6-9] reveal the importance of predictive tools-forecasts and scenarios in long-term planning.

\section{Current and Future Challenges Related to Water Use in Saskatchewan}

Water is a limited resource globally, but even more acutely so in semi-arid regions, such as parts of Saskatchewan. In recent years the province has seen an increase in water use, partially due to an increasing population but also as a result of increasing level of economic development activities. Beyond the increase in water use, Saskatchewan's water challenges will be aggravated by climate change. Intergovernmental Panel on Climate Change (IPCC) projections indicate that change in climate will reduce soil moisture and water availability in the Canadian Western Prairies [10,11]. These changes will affect the availability and quality of both surface and groundwater resources, while increases in water use will accentuate these issues further [12-14].

Water security is a Canadian priority both at the national and the local level. Saskatchewan commenced making steps forward by opening a dialogue in an attempt to understand its challenges and its future potential pathways towards a sustainable water use and management. Based on interviews with water stakeholders within the South Saskatchewan River Basin, competing water uses were assigned higher management priorities than biophysical related issues-flooding, drought, or long-term climate change [15]. These findings reverberate a well-known statement of United Nations [16]: "water crisis is essentially a crisis of governance and societies are facing a number of social, economic and political challenges on how to govern water more effectively".

*Corresponding author: Suren Kulshreshtha, School of Environment and Sustainability, University of Saskatchewan, Saskatoon, SK, S7N 5C8, Canada, Tel: +1306-966-4343; E-mail: suren.kulshreshtha@usask.ca

Received November 12, 2015; Accepted December 11, 2015; Published January 15,2016

Citation: Bogdan AM, Kulshreshtha S (2016) Temporal and Spatial Scale Community Level Water Use in Saskatchewan. J Aquac Res Development 7: 404. doi:10.4172/2155-9546.1000404

Copyright: $\odot 2016$ Bogdan AM, et al. This is an open-access article distributed under the terms of the Creative Commons Attribution License, which permits unrestricted use, distribution, and reproduction in any medium, provided the original author and source are credited. 


\section{Review of Available Studies}

The development of sound management strategies and policy frameworks that support sustainable use of water resources requires, amongst others, information regarding current and future water demand and supply levels. Within the Canadian literature, there are only few studies that have estimated community level water demand or use [17-23]. For Saskatchewan, the first reported study estimated total water use in various river basins including community level water use [22]. Being somewhat dated, this was followed by a study of water use patterns by river basins [23]. In a later study [24], total community water use was estimated without any disaggregation of type of community or factors that may affect future community water use.

Climate changes or policies for water conservation are likely to affect future water use probably by triggering behavioural changes amongst water users. Understanding these changes, or even making assumptions and incorporating these effects in future water use modelling in have the potential to support the development of sounder management plans. A significant amount of the recent Canadian literature on water management focuses on modelling the biophysical responses to climate change [25-27].

\section{Role of Forecasts and Scenarios in Developing a Sound Management Plan}

Forecasts under probable scenarios have the potential to inform the developers of comprehensive water management strategies. Future water use in any region is shaped by population, changes in economic activities as well as those in the biophysical system. Forecasts and explorative scenarios have the potential to answer important questions, such as: What will happen with municipal water uses levels 20 or 40 years from now or what could happen to water use levels given the impact of climate change? [7].

Much of the past research in domestic water use lacks modelling of community level economic attributes. In addition, there are only few studies incorporating climate change in municipal or domestic water use forecasts for Canada [20,28]. One may conclude that community level water use, although not an unstudied subject, needs a fresher look since much of the current studies for the province of Saskatchewan are outdated. The scope of this paper is to fill this data gap, in order to develop future policy frameworks and water management strategies in Saskatchewan. By providing information regarding water use levels at different administrative scales-individual communities, individual river basins and at the provincial level, the results can be used by local, regional or provincial water planners/managers. Also through the extended time horizon of the forecast, the results would support longterm planning, a necessity for water resources users, governing and managing stakeholders.

\section{Objectives of the Study}

The objectives of this study are fourfold: i) to estimate total community water use and use levels in Saskatchewan; ii) to further disaggregate the total community water use by location (river basins) and type of community; iii) to forecast total water use for each community type and river basin in Saskatchewan under three different future scenarios - baseline, climate change and water conservation; and (iv) to assess the impact of climate change and water conservation measures on disaggregated community water use in various locations and for Saskatchewan in the future $[29,30]$.

\section{Study Area}

With a land base of $570,113 \mathrm{~km}^{2}$ [31], Saskatchewan houses a population estimated at 1.105 million [32]. The province had an almost stagnant population, but in recent years has started to show moderate signs of growth - an increase by $11.6 \%$ in 2010 as compared to 1995 $[32,33]$. The province houses 26 watersheds, which are combined into 14 river basins, as shown in Figure 1.

\section{Methodology}

The total provincial population lives in a variety of communities. The majority of population is concentrated in communities located in the southern part of the province, predominantly in the Qu'Appelle, South Saskatchewan and North Saskatchewan River Basins, as shown in Figure 2. The province has experienced an urbanization trend, with large urban centers increasing over the past few decades, while rural communities are declining. In fact, in 2011, three quarters of the population lived in urban communities. Rural communities have decreased since 1995, currently accounting for $20 \%$ of the province's population.

In this study, the first distinction was made between rural and urban population, each of which included several types of communities. Urban population included cities, towns, and bedroom communities near large urban centers. Similarly, the rural population included those living in villages, open non-farm areas, and on farms. In addition, First Nations' Reserves, resort villages, and institutions were identified as separate categories for estimation of water use.

Total water use was estimated, in a disaggregated manner, as a sum of six types of water uses: (i) Municipal-for cities and other jurisdictions where a municipal water system is in place; (ii) Domestic (including municipal)-for towns and other larger urban centers other than cities; (iii) Rural-for villages; (iv) Institutional; (v) First Nations Reservations; and (vi) Other community water uses (such as farm and rural nonfarm water use). Total community level water use was a product of per capita water use and population of that given community, for each river basin. These water uses were estimated for 2010, 2020, 2040 and 2060, under three different scenarios: baseline, climate change and water conservation.

Total water use was a product of population of each center and per capita water use. For future time periods, 1995-2009 population was estimated using trend analysis using data obtained from [33]. Per capita water use was also projected using trend coupled with effect of size of community (population). The latter factor was reflective of economies of size and its effect on water management. The estimation was done individually for each of the types of communities.

In Saskatchewan most of the water for various types of uses is either obtained from surface water or groundwater. In some cases, groundwater is used to supplement any periodic shortfalls in surface water availability. However, data on groundwater resources remains very scarce [34]. Although some exact information was available, estimation in this study was based on assumptions related to on water withdrawal permits.

\section{Study Scenarios}

\section{Baseline scenario}

A baseline scenario is also called a "Business as Usual" scenario. It is generally used as a reference for comparison against an alternative scenario. Water use under the baseline scenario reflects an extension of 

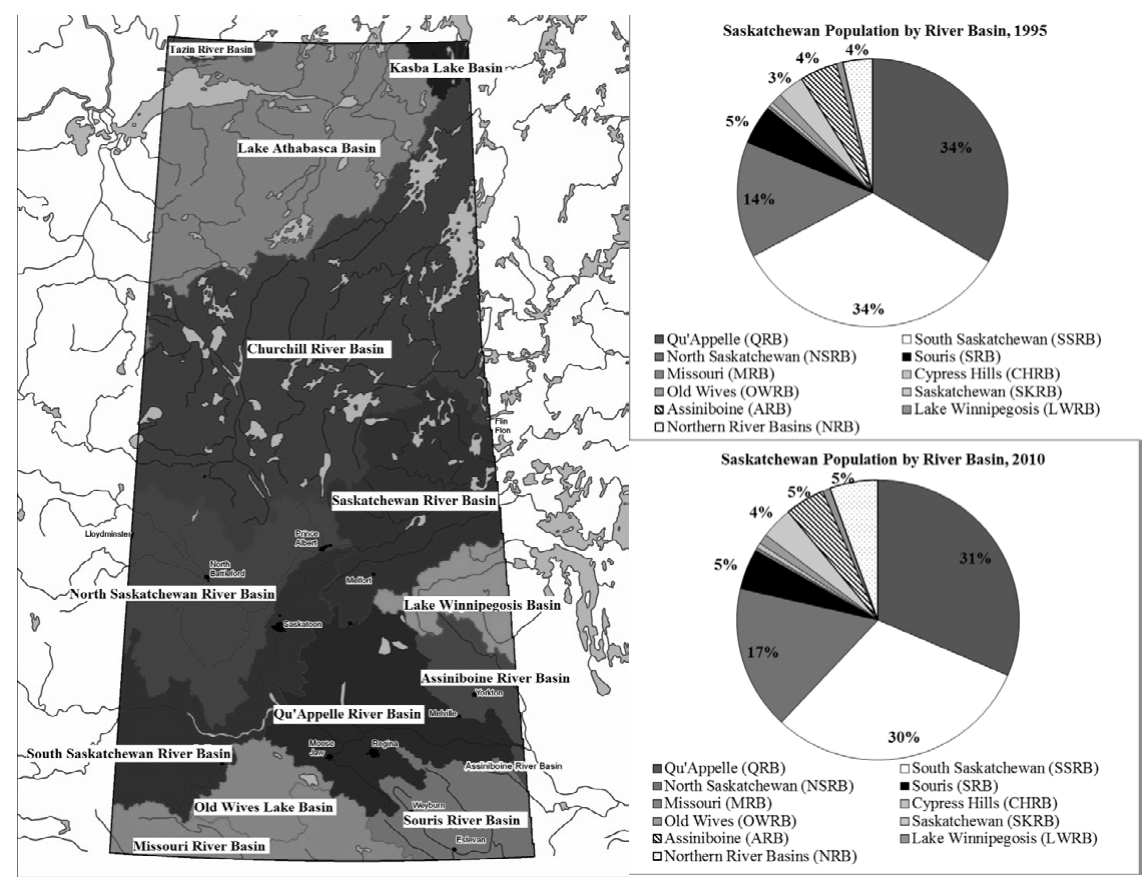

Figure 1: (a) (left) Map of Saskatchewan Showing Major River Basins, (SWA, 2012). (b) (right) Distribution of Saskatchewan Population by River Basin, 1995 and 2010.

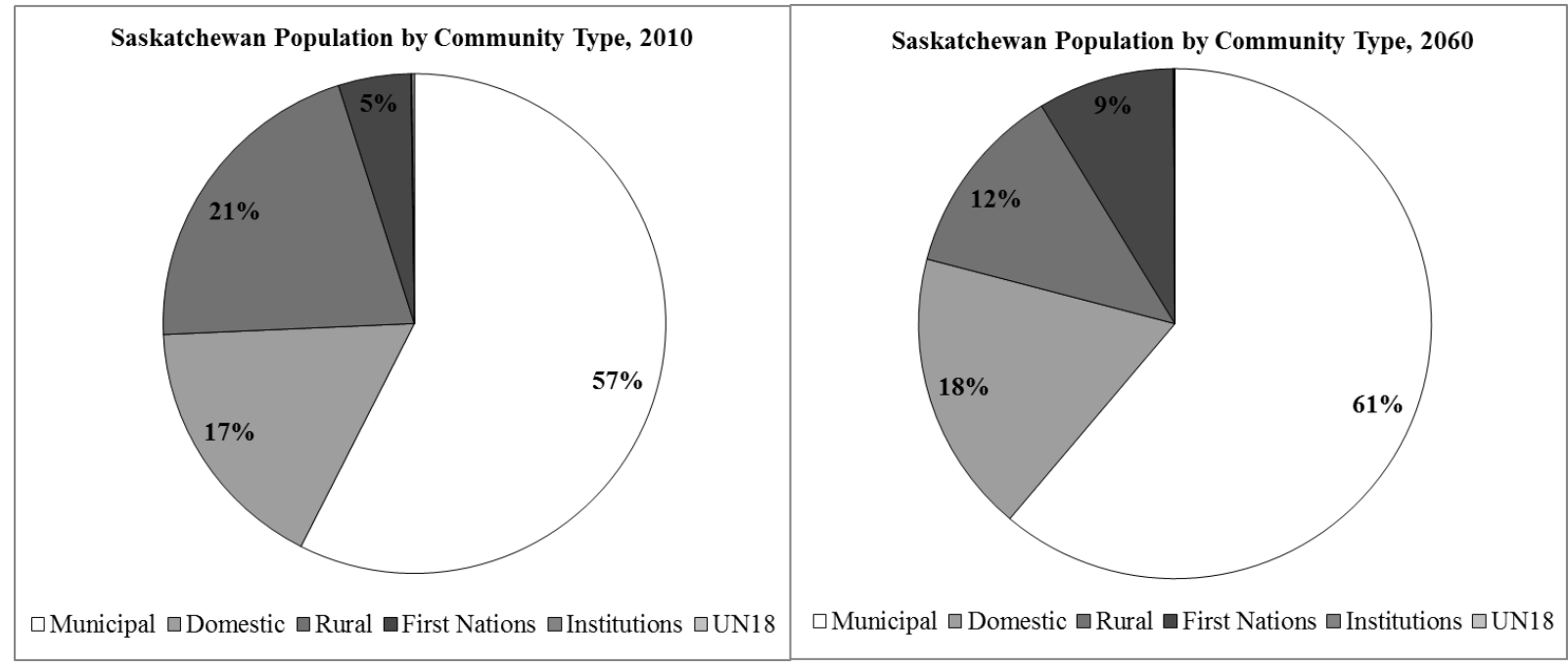

UN 18 means Unorganized Division 18 of Saskatchewan. This category included northern communities not included under any other groups. UN 18 communities are located for the most part in Churchill, Athabasca, Kasba and Tazin Basins.

Figure 2: Distribution of Saskatchewan population by community type, 2010-2060.

past trends in the future under informed assumptions. Estimates were made for the current period 2010, and projected to 2020, 2040, and 2060.

\section{Climate change scenario}

To estimate the effect of climate change, two aspects were taken into consideration: (i) temperature and precipitation change; and (ii) frequency of dry extreme events. Since no study reporting the impact of climate change on community water use in the basin was found, studies for other jurisdictions were reviewed.

Impact of climate change on UK domestic water use indicated an increase of 5\% in per capita water use by 2021 [35]. Within Canada, estimated impact of climate change in the Great Lakes region for May to September period water use was estimated to increase by 5.2 to $5.6 \%$ [36]. If one assumes that winter water use would remain unaffected, this 

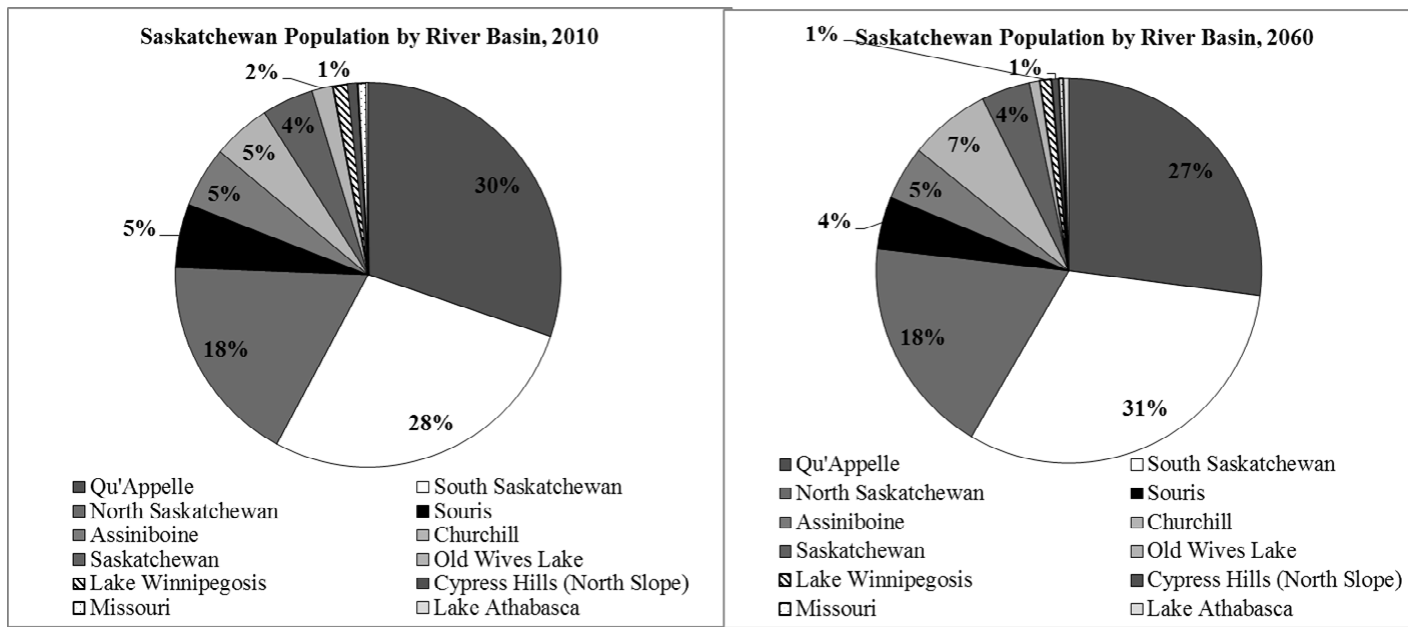

Figure 3: Distribution of Saskatchewan population by river basins, 2010-2060.

translates into a $2.5 \%$ and $2.4 \%$ increase on an annual basis.

Results from both of these studies were used in developing a climate change scenario for the basin. It was assumed that there will be no major climate change impacts on the basin's domestic water use by 2020 . Assuming that the average temperature in the basin for the climate change may be similar to the Great Lakes region, a $2.4 \%$ increase in domestic water use was assumed by 2040 . For 2060, an increase of $5 \%$ of the baseline scenario's level water use was assumed. Population predictions for all three time periods were the same as under the baseline scenario.

To estimate the impact of extreme events on community water use, per capita community water use data for 1995-2009 were used for each type of community. It was hypothesized that the 2001 and 2002 droughts would affect the level of water use in a positive manner. These events were introduced through a binary variable (which took a value of 1 if the year has an occurrence of drought, and 0 other wise) in the regression analysis. Other two variables-trend and size of the community, were retained for this analysis. Total water use for community purposes was a product of the adjusted water use coefficient and the population as used for the baseline scenario.

Water Conservation Scenario: This scenario involved adoption of water conservation practices. For community water use, an equal proportion of water used for indoor and for lawn irrigation was assumed. An adoption rate of $1 \%$ per annum was used for these practices.

Adjustment factors for municipal water conservation were based on the experience of Kelowna in British Columbia, where various conservation methods, such as meter installation, fixture replacement, rate increases, altered rate structure and public awareness programs, were included [36]. In this study it was assumed that savings in municipal water use would be of $2.5 \%$ by $2020,7.5 \%$ by 2040 and $12.5 \%$ by 2060 , relative to the baseline scenario. For non-municipal community water uses, lower saving rates were assumed: $0.58 \%$ by $2020,1.16 \%$ by 2040 and $2.9 \%$ by 2060 . These values were based on New Glasgow, Nova Scotia's experience [36].

\section{Results and Discussion}

\section{Population forecast by community type and river basins}

For the year 2010, Saskatchewan's population was estimated at 1.11 million which was expected to increase by approximately $32 \%$ by 2060 , reaching a total of 1.47 million people. As shown in Figure 3, there appears to be a moderate urbanization trend of the province's population over the forecast period. Currently, almost $74 \%$ of Saskatchewan's population resides in urban areas-57\% living in cities and $17 \%$ in towns and bedroom communities, $21 \%$ in rural communities, and nearly $5 \%$ of the population is represented by First Nations' people living on reserves. By 2060, the distribution of Saskatchewan's population is expected to change slightly. Currently, the urban centers are inhabited by 823,565 people and by 2060 , are foreseen to house more than a million people. Within this category, most of the population is concentrated in large cities, such as Regina and Saskatoon. The city of Saskatoon has the largest population in the province, and in the future is expected to record the highest growth rates.

In terms of geographical location, currently $76 \%$ of the provincial population is located in the Qu'Appelle, the South Saskatchewan, and the North Saskatchewan River Basins. The Qu'Appelle River Basin is currently the largest watershed in terms of population, inhabited by $30 \%$ of the province's population, followed by South Saskatchewan River Basin, with $28 \%$ and North Saskatchewan River Basin, with $18 \%$. The ranking of the basins is expected to change by 2060. The North Saskatchewan River Basin will preserve its share of the population and remain third, whereas the most populated watershed by 2060 is expected to be South Saskatchewan, which is foreseen to house $31 \%$ of Saskatchewan's population.

\section{Baseline scenario for community water use}

Current total community water use in Saskatchewan is estimated at $166,916 \mathrm{dam}^{3}$ (or 44,157 U.S. gallons) (Table 1), of which cities have the largest share. In fact, almost half of the total community water uses $(64 \%)$ are for the large urban centers. The next largest level of water use in 2010 is for rural communities, which included farm and rural non-farm level water uses, totalling $28,616 \mathrm{dam}^{3}$ (equivalent to 7,570 U.S. gallons). Following these two larger uses are community water uses (towns). By 2060, although municipal water use still has the largest share, the rank of other water sub-sectors does not change.

Table 2 shows the total community water use as well but in this instance by river basin. The majority of river basins are expecting growth in water use over the next period. In 2010 South Saskatchewan 
Citation: Bogdan AM, Kulshreshtha S (2016) Temporal and Spatial Scale Community Level Water Use in Saskatchewan. J Aquac Res Development 7: 404. doi:10.4172/2155-9546.1000404

Page 5 of 10

\begin{tabular}{|c|c|c|c|c|c|}
\hline \multirow{2}{*}{ Community Type } & \multicolumn{4}{|c|}{ Total water use $\left(\right.$ dam $\left.^{3}\right)$} & \multirow{2}{*}{$\begin{array}{c}\text { Change by } 2060 \text { as } \\
\% \text { of } 2010\end{array}$} \\
\hline & 2010 & 2020 & 2040 & 2060 & \\
\hline Cities & 105,971 & 111,480 & 124,958 & 140,087 & $32.2 \%$ \\
\hline Total Municipal Water Use & 105,971 & 111,480 & 124,958 & 140,087 & $32.2 \%$ \\
\hline Towns > 1000 & 16,586 & 16,550 & 16,345 & 16,106 & $-2.9 \%$ \\
\hline Towns $<1000$ & 6,491 & 6,487 & 6,647 & 6,860 & $5.7 \%$ \\
\hline Bedroom Communities & 1,865 & 2,410 & 3,641 & 5,260 & $182.0 \%$ \\
\hline Total Domestic Water Use & 24,942 & 25,447 & 26,633 & 28,226 & $13.2 \%$ \\
\hline Villages & 7,175 & 6,918 & 6,551 & 6,272 & $-12.6 \%$ \\
\hline Rural non-farm & 5,768 & 5,183 & 4,316 & 3,891 & $-32.5 \%$ \\
\hline Rural farm & 15,673 & 14,003 & 11,447 & 10,534 & $-32.8 \%$ \\
\hline Total Rural Water Use & 28,616 & 26,104 & 22,314 & 20,697 & $-27.7 \%$ \\
\hline First Nations & 5,461 & 6,611 & 10,677 & 15,459 & $183.1 \%$ \\
\hline Institutions & 327 & 300 & 252 & 204 & $-37.6 \%$ \\
\hline Unorganized Division 18 & 202 & 188 & 162 & 139 & $-31.2 \%$ \\
\hline Other & 385 & 414 & 474 & 534 & $38.8 \%$ \\
\hline Total Community Water Use Excluding IBT & 165,904 & 170,544 & 185,470 & 205,346 & $23.8 \%$ \\
\hline *IBT & 1,012 & 1,034 & 1,100 & 1,184 & $17.0 \%$ \\
\hline Total Municipal/Domestic Water Use Including Inter-basin Transfers & 166,916 & 171,578 & 186,570 & 206,530 & $23.7 \%$ \\
\hline
\end{tabular}

*Interbasin transfers include water uses of communities located in a particular basin but receive their water supplies from another basin; one example is the City of Humboldt. It is located in the Qu'Appelle River Basin but water is supplied by South Saskatchewan River Basin

Table 1: Total community water use estimates for Saskatchewan, by community type under baseline scenario 2010, 2020,2040 and 2060.

\begin{tabular}{|c|c|c|c|c|c|}
\hline \multirow[b]{2}{*}{ River Basin } & \multicolumn{4}{|c|}{ Total water use $\left(\mathrm{dam}^{3}\right)$} & \multirow[b]{2}{*}{$\begin{array}{l}\text { Change by } 2060 \text { as \% of } \\
2010\end{array}$} \\
\hline & 2010 & 2020 & 2040 & 2060 & \\
\hline Assiniboine & 6,712 & 6,852 & 7,266 & 7,931 & $18.2 \%$ \\
\hline Cypress Hills & 1,345 & 1,320 & 1,298 & 1,355 & $0.7 \%$ \\
\hline Lake Winnipegosis & 2,480 & 2,209 & 1,799 & 1,558 & $-37.2 \%$ \\
\hline Missouri & 1,338 & 1,296 & 1,155 & 1,130 & $-15.5 \%$ \\
\hline North Saskatchewan & 26,425 & 27,009 & 29,620 & 32,293 & $22.2 \%$ \\
\hline Northern Four & 7,310 & 7,792 & 9,954 & 12,137 & $66.0 \%$ \\
\hline Old Wives & 3,038 & 2,916 & 2,633 & 2,554 & $-15.9 \%$ \\
\hline Qu'Appelle & 45,689 & 44,852 & 44,512 & 45,607 & $-0.2 \%$ \\
\hline Saskatchewan & 5,270 & 5,456 & 5,846 & 6,470 & $22.8 \%$ \\
\hline Souris & 8,622 & 8,683 & 8,834 & 9,215 & $6.9 \%$ \\
\hline South Saskatchewan & 57,676 & 62,160 & 72,553 & 85,097 & $47.5 \%$ \\
\hline Total Municipal/Domestic Water Use Excluding IBT & 165,904 & 170,544 & 185,470 & 205,346 & $23.8 \%$ \\
\hline${ }^{*} \mathrm{IBT}$ & 1,012 & 1,034 & 1,100 & 1,184 & $17.0 \%$ \\
\hline Total Municipal/Domestic Water Use Including IBT & 166,916 & 171,578 & 186,570 & 206,530 & $23.7 \%$ \\
\hline
\end{tabular}

Table 2: Total community water use estimates for Saskatchewan by river basin under baseline scenario, 2010-2060.

was the largest river basin in terms of community water consumption, accounting for $35 \%$ of the total water use. It is expected to further increase by 7\% in 2060. The Qu'Appelle and North Saskatchewan River Basins represented $27 \%$ and $16 \%$, respectively, of the total community water use in Saskatchewan. The Qu'Appelle River Basin is assumed to reduce its water use by $5 \%$ in 2060 , whereas North Saskatchewan River Basin is expected to maintain its water use levels.

\section{Climate change scenario community water use}

Community water use levels are expected to increase under the climate change scenario. Increases are expected in all jurisdictions of community water use. Total water use in 2060 would increase to $218,266 \mathrm{dam}^{3}$ (equivalent to 57,742 U.S. gallons) per annum, which is nearly $31 \%$ higher than in 2010 (Table 3). Results also suggest that total community water use under the climate change scenario for more urbanized river basins (South Saskatchewan, North Saskatchewan, and Assiniboine) would increase significantly. Same trend is expected for the Northern Four river basins but more as a result of population growth (Table 4). 


\begin{tabular}{|c|c|c|c|c|c|}
\hline \multirow[t]{2}{*}{ River Basin } & \multicolumn{4}{|c|}{ Total water use $\left(\right.$ dam $\left.^{3}\right)$} & \multirow[t]{2}{*}{ Change by 2060 as $\%$ of 2010} \\
\hline & 2010 & 2020 & 2040 & 2060 & \\
\hline Cities & 105,971 & 111,480 & 128,540 & 148,006 & $39.7 \%$ \\
\hline Total Municipal Water Use & 105,971 & 111,480 & 128,540 & 148,006 & $39.7 \%$ \\
\hline Towns > 1000 & 16,586 & 16,550 & 17,035 & 17,305 & $4.3 \%$ \\
\hline Towns $<1000$ & 6,491 & 6,487 & 6,892 & 7,290 & $12.3 \%$ \\
\hline Bedroom Communities & 1,865 & 2,410 & 3,729 & 5,523 & $196.1 \%$ \\
\hline Total Domestic Water Use & 24,942 & 25,447 & 27,656 & 30,118 & $20.8 \%$ \\
\hline Villages & 7,175 & 6,918 & 6,707 & 6,582 & $-8.3 \%$ \\
\hline Rural non-farm & 5,768 & 5,183 & 4,418 & 4,084 & $-29.2 \%$ \\
\hline Rural farm & 15,673 & 14,003 & 11,721 & 11,060 & $-29.4 \%$ \\
\hline Total Rural Water Use & 28,616 & 26,104 & 22,846 & 21,726 & $-24.1 \%$ \\
\hline First Nations & 5,461 & 6,611 & 10,934 & 16,232 & $197.2 \%$ \\
\hline Institutions & 327 & 300 & 271 & 230 & $-29.7 \%$ \\
\hline Unorganized Division 18 & 202 & 188 & 165 & 146 & $-27.7 \%$ \\
\hline Other & 385 & 414 & 485 & 560 & $45.6 \%$ \\
\hline Total Community Water Use Excluding IBT & 165,904 & 170,544 & 190,897 & 217,018 & $30.8 \%$ \\
\hline *IBT & 1,012 & 1,034 & 1,130 & 1,248 & $23.3 \%$ \\
\hline Total Municipal/Domestic Water Use Including IBT & 166,916 & 171,578 & 192,027 & 218,266 & $30.7 \%$ \\
\hline Change \% over Baseline Scenario & $0.0 \%$ & $0.0 \%$ & $2.9 \%$ & $5.7 \%$ & \\
\hline
\end{tabular}

Table 3: Total community water use estimates for Saskatchewan by community type under climate change scenario, $2010-2060$.

\begin{tabular}{|c|c|c|c|c|c|}
\hline & \multicolumn{4}{|c|}{ Total water use $\left(\mathrm{dam}^{3}\right)$} & \multirow{2}{*}{ Change by 2060 as \% of 2010} \\
\hline & 2010 & 2020 & 2040 & 2060 & \\
\hline Assiniboine & 6,712 & 6,852 & 7,442 & 8,326 & $24.0 \%$ \\
\hline Cypress Hills & 1,345 & 1,320 & 1,329 & 1,422 & $5.7 \%$ \\
\hline Lake Winnipegosis & 2,480 & 2,209 & 1,842 & 1,636 & $-34.0 \%$ \\
\hline Missouri & 1,338 & 1,296 & 1,181 & 1,186 & $-11.4 \%$ \\
\hline North Saskatchewan & 26,425 & 27,009 & 31,200 & 35,236 & $33.3 \%$ \\
\hline Northern Four & 7,310 & 7,792 & 10,193 & 12,744 & $74.3 \%$ \\
\hline Old Wives & 3,038 & 2,916 & 2,696 & 2,683 & $-11.7 \%$ \\
\hline Qu'Appelle & 45,689 & 44,852 & 45,652 & 47,950 & $4.9 \%$ \\
\hline Saskatchewan & 5,270 & 5,456 & 5,986 & 6,791 & $28.9 \%$ \\
\hline Souris & 8,622 & 8,683 & 9,047 & 9,674 & $12.2 \%$ \\
\hline South Saskatchewan & 57,676 & 62,160 & 74,330 & 89,370 & $55.0 \%$ \\
\hline Total Municipal/Domestic Water Use Excluding IBT & 165,904 & 170,544 & 190,897 & 217,018 & $30.8 \%$ \\
\hline${ }^{*} \mathrm{IBT}$ & 1,012 & 1,034 & 1,130 & 1,248 & $23.3 \%$ \\
\hline Total Municipal/Domestic Water Use Including IBT & 166,916 & 171,578 & 192,027 & 218,266 & $30.7 \%$ \\
\hline
\end{tabular}

Table 4: Total community water use estimates for Saskatchewan by river basins under climate change scenario, 2010-2060.

\section{Community water use under water conservation scenario}

This study also estimated the effect of adoption of water conservation measures on community water use. In comparison to the baseline scenario, the water conservation scenario is estimated to be nearly $7.9 \%$ lower by 2060 over the baseline level of water use-a reduction from 206,530 dam ${ }^{3}$ (equivalent to 54,638 U.S. gallons) to $190,216 \mathrm{dam}^{3}$ (equivalent to 50,322 U.S. gallons) (Table 5).

Table 6 shows the effect of employing water conservation practices by river basin. All river basins are assumed to record savings in water use, determining a slower overall growth rate. It is expected that under the water conservation scenario water use will increase only by approximately $14 \%$ by 2060 .

\section{Source of water for community water use}

Community water uses are served both by surface water bodies and by underground aquifers. A summary of this water use for the baseline scenario is shown in Table 7. Almost three quarters of the total community water use is met by surface water bodies. Groundwater is used mostly in non-urban communities and by some industries (located near large urban centers). The relative proportion of surface to groundwater varies slightly among the three scenarios. The use for surface water dominates the total water use for community purposes in Saskatchewan. In 2010, $74 \%$ of the total water use was served from such sources. It increases to approximately $76 \%$ by 2060 .

The source of water for community water use varies greatly from one basin to another. Highly urbanized basins such as South Saskatchewan, Qu'Appelle, and North Saskatchewan) rely more on surface water than other basins. For example, surface water represents only $29 \%$ of the total water supply in the Missouri River Basin and 34\% in the Assiniboine River Basin. In the Northern Four and in the South Saskatchewan River Basins, the share is much higher, $85 \%$ and $96 \%$ respectively (Figure 4 ).

\section{Summary of total community water use}

Trends in the community water use in Saskatchewan under the three 


\begin{tabular}{|c|c|c|c|c|c|}
\hline \multirow{2}{*}{ River Basin } & \multicolumn{4}{|c|}{ Total water use $\left(\mathrm{dam}^{3}\right)$} & \multirow{2}{*}{$\begin{array}{l}\text { Change by } 2060 \text { as } \% \text { of } \\
2010\end{array}$} \\
\hline & 2010 & 2020 & 2040 & 2060 & \\
\hline Cities & 105,971 & 109,376 & 117,574 & 125,798 & $18.7 \%$ \\
\hline Total Municipal Water Use & 105,971 & 109,376 & 117,574 & 125,798 & $18.7 \%$ \\
\hline Towns $>1000$ & 16,586 & 16,349 & 16,151 & 15,639 & $-5.7 \%$ \\
\hline Towns $<1000$ & 6,491 & 6,447 & 6,567 & 6,658 & $2.6 \%$ \\
\hline Bedroom Communities & 1,865 & 2,396 & 3,598 & 5,107 & $173.8 \%$ \\
\hline Total Domestic Water Use & 24,942 & 25,192 & 26,316 & 27,404 & $9.9 \%$ \\
\hline Villages & 7,175 & 6,850 & 6,471 & 6,088 & $-15.1 \%$ \\
\hline Rural non-farm & 5,768 & 5,144 & 4,262 & 3,779 & $-34.5 \%$ \\
\hline Rural farm & 15,673 & 13,895 & 11,310 & 10,229 & $-34.7 \%$ \\
\hline Total Rural Water Use & 28,616 & 25,889 & 22,043 & 20,096 & $-29.8 \%$ \\
\hline First Nations & 5,461 & 6,571 & 10,551 & 15,010 & $174.9 \%$ \\
\hline Institutions & 327 & 300 & 249 & 194 & $-40.7 \%$ \\
\hline Unorganized Division 18 & 202 & 186 & 160 & 135 & $-33.2 \%$ \\
\hline Other & 385 & 413 & 467 & 516 & $34.0 \%$ \\
\hline Total Municipal/Domestic Water Use Excluding IBT & 165,904 & 167,927 & 177,360 & 189,153 & $14.0 \%$ \\
\hline${ }^{*} \mathrm{~B} \mathrm{BT}$ & 1,012 & 1,016 & 1,035 & 1,063 & $5.0 \%$ \\
\hline Total Municipal/Domestic Water Use Including IBT & 166,916 & 168,943 & 178,395 & 190,216 & $13.9 \%$ \\
\hline$\%$ Change over Baseline Scenario & $0.0 \%$ & $-1.5 \%$ & $-4.4 \%$ & $-7.9 \%$ & \\
\hline
\end{tabular}

Table 5: Total community water use estimates for Saskatchewan by community type under water conservation Scenario, $2010-2060$.

\begin{tabular}{|c|c|c|c|c|c|}
\hline \multirow{2}{*}{ River Basin } & \multicolumn{4}{|c|}{ Total water use $\left(\mathrm{dam}^{3}\right)$} & \multirow{2}{*}{$\begin{array}{l}\text { Change by } 2060 \text { as \% of } \\
2010\end{array}$} \\
\hline & 2010 & 2020 & 2040 & 2060 & \\
\hline Assiniboine & 6,712 & 6,764 & 6,987 & 7,357 & $9.6 \%$ \\
\hline Cypress Hills & 1,345 & 1,313 & 1,282 & 1,316 & $-2.1 \%$ \\
\hline Lake Winnipegosis & 2,480 & 2,197 & 1,776 & 1,512 & $-39.0 \%$ \\
\hline Missouri & 1,338 & 1,288 & 1,140 & 1,096 & $-18.1 \%$ \\
\hline North Saskatchewan & 26,425 & 26,579 & 28,217 & 29,535 & $11.8 \%$ \\
\hline Northern Four & 7,310 & 7,560 & 9,759 & 11,648 & $59.3 \%$ \\
\hline Old Wives & 3,038 & 2,898 & 2,601 & 2,482 & $-18.3 \%$ \\
\hline Qu'Appelle & 45,689 & 44,631 & 43,900 & 44,404 & $-2.8 \%$ \\
\hline Saskatchewan & 5,270 & 5,411 & 5,735 & 6,224 & $18.1 \%$ \\
\hline Souris & 8,622 & 8,544 & 8,412 & 8,424 & $-2.3 \%$ \\
\hline South Saskatchewan & 57,676 & 60,742 & 67,551 & 75,154 & $30.3 \%$ \\
\hline Total Community Water Use Excluding IBT & 165,904 & 167,927 & 177,360 & 189,153 & $14.0 \%$ \\
\hline *IBT & 1,012 & 1,016 & 1,035 & 1,063 & $5.0 \%$ \\
\hline Total Community Water Use Including IBT & 166,916 & 168,943 & 178,395 & 190,216 & $13.9 \%$ \\
\hline
\end{tabular}

Table 6: Total community water use estimates for Saskatchewan by river basins under water conservation Scenario, $2010-2060$.

study scenarios - baseline, climate change and water conservation, are shown in Figure 5. All scenarios provide the same pattern. In all cases, climate change (after 2020) will bring forth increases in water use for community purposes, an increase of $5.7 \%$ over the baseline scenario. Adoption of water conservation practices would reduce this water use level by $7.9 \%$.

Total community water use by various river basins is shown in Figure 6. It is expected that developments in the South Saskatchewan River Basin will determine the trend in municipal/domestic water use in Saskatchewan, as its share of the total water use is expected to grow over the next period.

\section{Conclusions and Recommendations}

\section{Baseline scenario}

Based on the community water use estimates under a baseline scenario, it appears that water use for this purpose will increase in some river basins, particularly in the South Saskatchewan, North Saskatchewan and Qu'Appelle River Basins. These basins have large urban centers and the increase in water use is mostly driven by the expansion of urban population and related manufacturing activities. Conversely in basins where the rural population is rapidly decreasing, water use levels be lower as well. Saskatchewan has $76 \%$ of its population concentrated in the southern half of the province, in the three aforementioned basins. An increase in population of nearly $32 \%$ is expected by 2060 under current trends, which will lead to an increase in water use levels by $23.7 \%$ by 2060 . Although municipal water use is already a very important use of water in the basin, its share is expected to increase in the future. This together with a potential decrease in water supply could pose management challenges going into the future. Whether this would result in water scarcity or tough competition among various water users will be determined by other factors including future policies and management strategies, including factors affecting its availability. 


\section{Climate change scenario}

One of the factors that may affect water resources is climate change. Semi-arid and arid areas, such as Saskatchewan, are particularly exposed to the impacts of climate change in freshwater. These effects on community water use levels are expected to take place by 2040 . Based on the estimations made under this set of assumptions, water use is expected to increase by $5.7 \%$ by 2060 over the baseline scenario estimated levels. However, our knowledge base for determining its impact of climate change on water use is rather weak. More research needs to be undertaken during the period of droughts and extreme rain events in order to make more robust estimates.

\section{Water conservation scenario}

As competition for the available water increases, there may be a need for use management. Measures encouraging water conservation may become more important in the future. Water conservation offers the province a way to reduce future water stress. Based on the estimates under this scenario, a reduction of $7.9 \%$ in water use levels over the baseline scenario is possible. Water conservation is especially important in the face of increasing water use in the face of climate change impacts. Although such measures might not be able to offset the increases triggered by climate change, particularly during periods of droughts, they do offer an avenue for a sound future water management. Water pricing and educating users about the merits of adopting such measures are often noted as the most important factors affecting adoption of water conservation practices. NRTEE [5] has also suggested the potential of two emerging policy instruments for water conservation - water pricing and voluntary initiatives.

\section{Limitations and future research}

In this study, several assumptions were made which could be improved with additional data. This study calculated water use coefficients by using the best available data. Estimation of a use function by type of use is important if decision making is to involve adjustments

\begin{tabular}{|l|c|c|c|c|}
\hline \multirow{2}{*}{ Particulars } & \multicolumn{4}{|c|}{ Water use in dam } \\
\cline { 2 - 5 } & $\mathbf{2 0 1 0}$ & $\mathbf{2 0 2 0}$ & $\mathbf{2 0 4 0}$ & $\mathbf{2 0 6 0}$ \\
\hline Total Community Water Use & 165,904 & 170,544 & 185,470 & 205,346 \\
\hline Surface Water & 123,433 & 128,079 & 141,328 & 156,884 \\
\hline Groundwater & 42,471 & 42,465 & 44,142 & 48,462 \\
\hline Surface water as \% of total water use & $\mathbf{7 4 . 4 \%}$ & $\mathbf{7 5 . 1 \%}$ & $\mathbf{7 6 . 2} \%$ & $\mathbf{7 6 . 4 \%}$ \\
\hline
\end{tabular}

Table 7: Total community water use by source, Saskatchewan, baseline scenario, 2010-2060. in water pricing or water conservation. These use functions would require primary data collection involving information on quantity, cost to the user, and other factors that affect water use.

Community water use was estimated by employing a trend projection method. In many cases, it yielded unreasonable results. Better forecasting models need to be developed for these water uses. Improved population forecasts could significantly improve the estimation of communities' water use levels as well. For cities and towns, water use was estimated without further disaggregating it between residential and non-residential uses. Within these communities, there are several types of uses in addition to the residential use for water, such as manufacturing, commercial, firefighting, street cleaning, and other public uses. Further research is needed to estimate disaggregate water use for these communities in order to obtain a better basis for water management, particularly under climate change and water conservation measures.

Some communities receive surface water through rural pipelines. This information was not used in this study since it is not readily available. Further investigation of this source of water is needed. Better data collection on this aspect is highly recommended. Studies on the level of return flow of water from smaller communities were not found. An investigation of this aspect of water use is required.

This study estimated and explored future community water uses under different scenarios or sets of assumptions. It is important to emphasize that the focus should be on the magnitude of difference between the three scenarios rather than the exact figures of water use levels, bearing in mind the sets of assumptions that were made for this modeling exercise and the data limitations. The scenarios allow for an exploration of alternative water futures and have the potential to inform long-term planning and development of sounder water management strategies. Improved water-demand management starts with strong principles that value water so it can be conserved and used efficiently. Sustainable water demand will come from better knowledge and application of four key knowledge areas: water forecasts, water quantity data and information, policy instruments, and collaborative water governance [5].

Putting forward water management strategies and policy frameworks for a sustainable use of water resources in Saskatchewan and across the world cannot be by only using past trends as reference, especially in highly dynamic socio-economic contexts and with uncertain future environmental changes. Making use of alternative
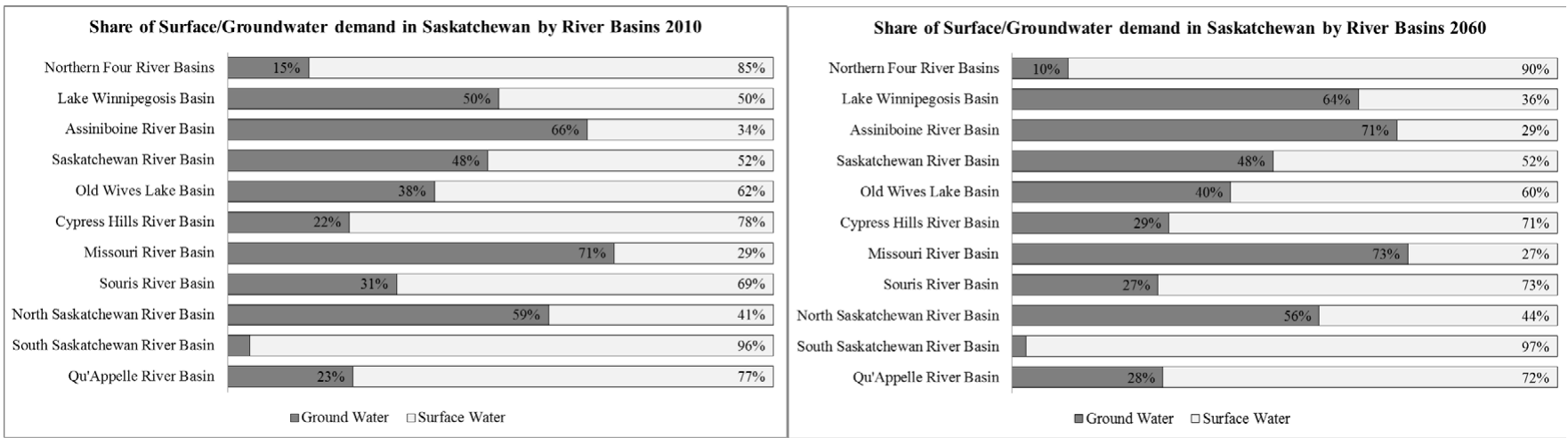

Figure 4: Share of surface/groundwater use in Saskatchewan by river basins, 2010-2060 
Citation: Bogdan AM, Kulshreshtha S (2016) Temporal and Spatial Scale Community Level Water Use in Saskatchewan. J Aquac Res Development 7: 404. doi:10.4172/2155-9546.1000404

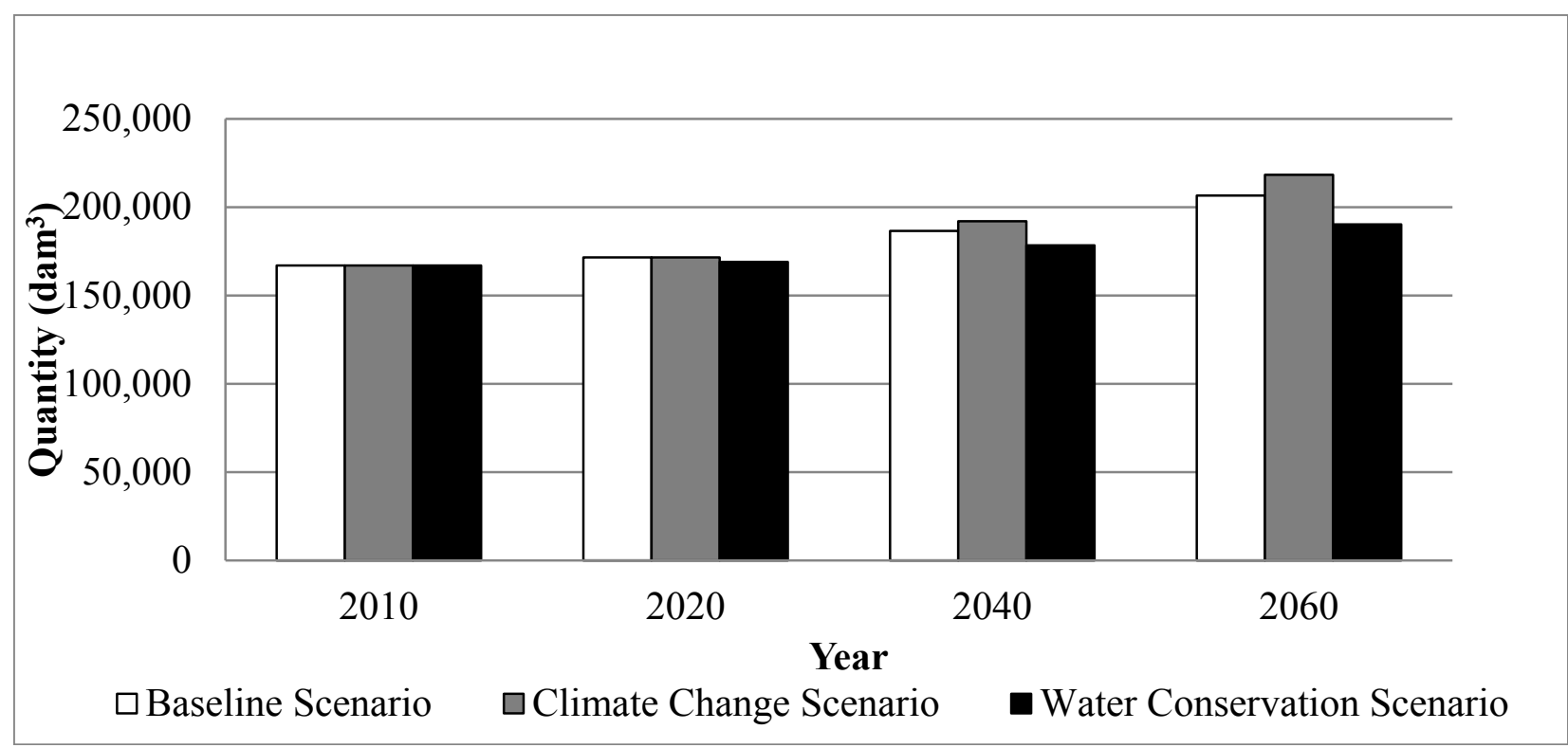

Figure 5: Total community water use for Saskatchewan under study scenarios, 2010-2060.

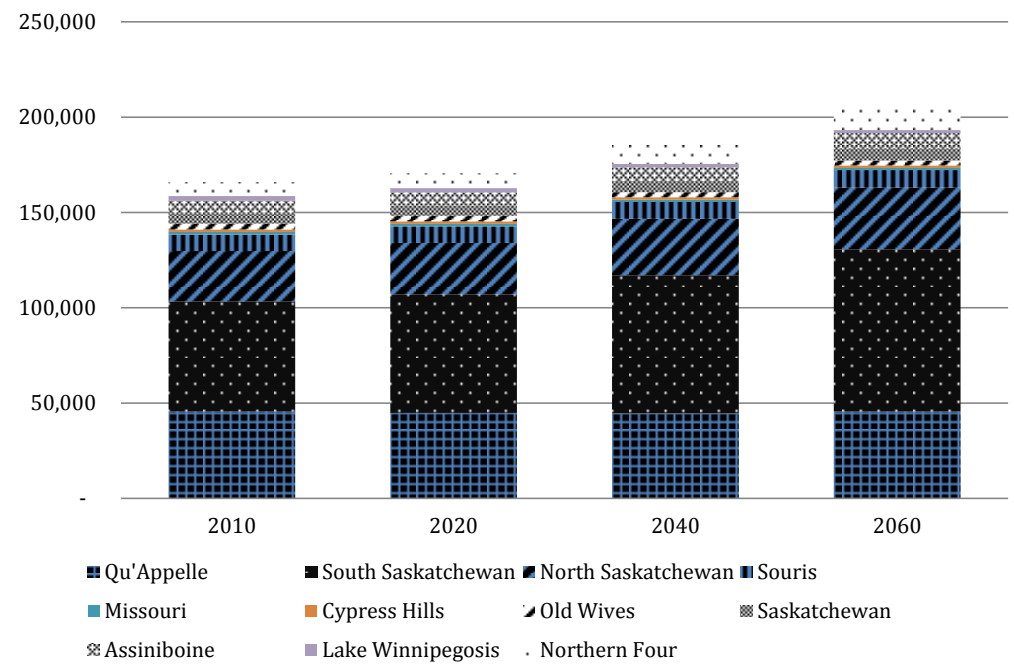

Figure 6: Community water use in Saskatchewan by river basin, baseline scenario 2010-2060.

managerial approaches such as demand side management and novel planning tools - scenario building, back casting, etc., have the potential to support robust decision-making and potentially alleviate some future related problems. Even though not without limitations, this study showed that following a municipal water conservation scenario for managing water resources might offset the increase in the water use levels brought forward by climate change. Based on the findings of this study, it is sensible that water governance shifts towards sounder policies that enable the adoption of technologies and practices that lead to a conservation of this valuable resource.

\section{Acknowledgements}

This report is based on a study funded by the Saskatchewan Watershed Authority and South Central Economic Region. This funding is gratefully acknowledged.

\section{References}

1. Young GJ (2009) Challenges for water managers: can science help to solve the problems? IAHS-AISH publication 327: 9-17.

2. Gleick PH, Ajami N (2014) The World's Water Volume 8: The Biennial Report on Freshwater Resources. Island Press.

3. Vörösmarty CJ, Mclntyre PB, Gessner MO, Dudgeon D, Prusevich A, et al (2010) Global threats to human water security and river biodiversity. Nature 467: 555-561.

4. UN-United Nations (2012) Managing Water under Uncertainty and Risk. World Water Development Report 4. Paris: UNESCO Publishing.

5. NRTEE-National Round Table on the Environment and the Economy (2012) Charting a Course: Sustainable Water by Canada's Natural Resource Sectors. Ottawa: NRTEE.

6. Berkhout F, Hertin J, Jordan A (2002) Socio-economic futures in climate 
Citation: Bogdan AM, Kulshreshtha S (2016) Temporal and Spatial Scale Community Level Water Use in Saskatchewan. J Aquac Res Development 7: 404. doi:10.4172/2155-9546.1000404

Page 10 of 10

change impact assessment: using scenarios as 'learning machines'. Global Environmental Change 12: 83-95.

7. Börjeson L, Höjer M, Dreborg KH, Ekvall T, Finnveden G (2006) Scenario types and techniques: towards a user's guide. Futures 38: 723-739.

8. Haasnoot M, Middelkoop H, Van Beek E, Van Deursen WPA (2011) A method to develop sustainable water management strategies for an uncertain future. Sustainable Development 19: 369-381.

9. Amer M, Daim TU, Jetter A (2013) A review of scenario planning. Futures 46: 23-40.

10. Romero-Lankao P, Smith JB, Davidson DJ, Diffenbaugh NS, Kinney PL, et al. (2014) North America. In: Climate Change 2014: Impacts, Adaptation, and Vulnerability. Part B: Regional Aspects. Contribution of Working Group II to the Fifth Assessment Report of the Intergovernmental Panel on Climate Change. In: Barros VR, Field CB, Dokken DJ, Mastrandrea MD, Mach KJ, et al. (eds.). Cambridge University Press, Cambridge, United Kingdom and New York, NY, USA pp. 1439-1498.

11. Kulshreshtha SN (2011) Climate change, prairie agriculture, and prairie economy: the new normal. Canadian Journal of Agricultural Economics/Revue canadienne d'agroeconomie 59: 19-44.

12. Lemmen DS, Warren FJ, Lacroix J, Bush E (2008) From Impacts to Adaptation: Canada in a Changing Climate 2007, 448 pp. Ottawa, ON: Government of Canada.

13. Kulshreshtha SN, Nagy C, Bogdan AM (2012) Present and Future Water Demand in Saskatchewan-A Summary by River Basins. Report prepared for Saskatchewan Watershed Authority.

14. SWA-Saskatchewan Watershed Authority (2012) Saskatchewan Watershed Authority Annual Report 2011-12.

15. Gober PA, Strickert GE, Clark DA, Chun KP, Payton D, et al. (2015) Divergent perspectives on water security: bridging the policy debate. The Professional Geographer 67: 62-71.

16. UN-United Nations (2003) Water for People, Water for Life. World Water Development Report 1. Paris: UNESCO Publishing, Berghahn Books, New York, USA

17. Tate D, Lacelle D (1978) Municipal water use in Canada. Canadian Water Resources Journal 3: 61-78.

18. Harris J (1992) Statistical estimation of a residential water demand function in Quebec. Canadian Water Resources Journal 17: 95-100.

19. Fullerton Jr TM, White KC, Doyle SW, Walke AG (2013) An empirical analysis of Halifax municipal water consumption. Canadian Water Resources Journal 38: $148-158$

20. Neale T, Carmichael J, Cohen S (2007) Urban Water Futures: A multivariate analysis of population growth and climate change impacts on urban water demand in the Okanagan Basin, BC. Canadian Water Resources Journal 32: 315-330.

21. Renzetti S, Brandes OM, Dupont DP, MacIntyre-Morris T, Stinchcombe K (2015) Using demand elasticity as an alternative approach to modelling future community water demand under a conservation-oriented pricing system: An exploratory investigation. Canadian Water Resources Journal/Revue canadienne des ressources hydriques 40: 62-70.

22. PPWB-Prairie Provinces Water Board (1982) Water demand Study-Historical and Current Water Demands in the Saskatchewan-Nelson Basin. Regina.

23. Kulshreshtha SN, Brockman J, O'Grady K, Miller S (1988) Current Water Demand Levels in Saskatchewan. Water Demand and Value Report No. 3. Moose Jaw: Saskatchewan Water Corporation.

24. Cohen S, Koshida G, Mortsch L (2015) Climate and water availability indicators in Canada: Challenges and a way forward. Part III-Future scenarios. Canadian Water Resources Journal/Revue canadienne des ressources hydriques 40: 160-172.

25. Koshida G, Cohen S, Mortsch L (2015) Climate and water availability indicators in Canada: Challenges and a way forward. Part I-Indicators. Canadian Water Resources Journal/Revue canadienne des ressources hydriques 40: 133-145.

26. Mortsch L, Cohen S, Koshida G (2015) Climate and water availability indicators in Canada: Challenges and a way forward. Part II-Historic trends. Canadian Water Resources Journal/Revue canadienne des ressources hydriques 40: 149-159.

27. Harma KJ, Johnson MS, Cohen SJ (2012) Future water supply and demand in the Okanagan Basin, British Columbia: a scenario-based analysis of multiple, interacting stressors. Water Resources Management 26: 667-689.

28. Durance P, Godet M (2010) Scenario building: uses and abuses. Technological Forecasting and Social Change 77: 1488-1492.

29. Stojanović M, Mitković P, Mitković M (2014) The scenario method in urban planning. Facta universitatis-series: Architecture and Civil Engineering 12: 81-95.

30. SAFRR-Saskatchewan Agriculture and Food and Rural Revitalization (2003) Agricultural Statistics 2001, Regina.

31. Statistics Canada (2012) Census Profiles.

32. SWA-Saskatchewan Watershed Authority (2011) Saskatchewan Community Water use Records 1995 to 2010. Report No. 24.

33. Rivera A (2005) Case Study - How well do we understand groundwater in Canada? A science case study. In L Nowlan, Buried Treasure - Groundwater Permitting and Pricing in Canada. ON: Water and Duncan Gordon Foundation, Toronto, Canada.

34. Herrington $P$ (1996) Climate Change and the Demand for Water. HMSO, London.

35. Cohen SJ (1985) Effects of climatic variations on water withdrawals in metropolitan Toronto. The Canadian Geographer/Le Géographe canadien 29: 113-122.

36. Waller DH, Scott RS (1998) Canadian municipal residential water conservation initiatives. Canadian Water Resources Journal 23: 369-406. 